\title{
The future of public efforts to boost entrepreneurship and venture capital
}

\author{
Josh Lerner
}

Accepted: 3 July 2010/Published online: 27 July 2010

(C) Research Institute of Industrial Economics 2010. This article is published with open access at Springerlink.com

\begin{abstract}
The promotion of new high-potential business ventures and venture capital is of critical importance to economic growth. Well-considered policies can profoundly influence such opportunities, but many public initiatives are misguided. This article reviews the evidence behind these claims, as well as the criteria that can delineate appropriate and inappropriate policies towards the promotion of venture capital and high-potential entrepreneurship.
\end{abstract}

Keywords Entrepreneurship · Entrepreneurship policy $\cdot$ Innovation $\cdot$ Venture capital

JEL Classifications $\quad \mathrm{G} 24 \cdot \mathrm{O} 31 \cdot \mathrm{O} 38 \cdot \mathrm{L} 26$

\section{Introduction}

Silicon Valley, Singapore, Tel Aviv-the global hubs of entrepreneurial activity all bear the marks of

Josh Lerner is the 2010 Winner of the Global Award for Entrepreneurship Research. This essay is the Prize Lecture given upon receipt of the Award on 26 May 2010 in Stockholm, Sweden. For more information about the Prize and previous Winners see www.e-award.org and Henrekson and Lundström (2009). This lecture is based on Lerner (2009).

\section{J. Lerner $(\bowtie)$}

Harvard Business School and National Bureau of Economic Research, Cambridge, MA, USA e-mail: josh@hbs.edu government investment. However, for every successful public intervention spurring entrepreneurial activity, there are many failed efforts, wasting untold billions in taxpayer dollars. When has governmental sponsorship succeeded in boosting growth, and when has it fallen terribly short? Should government be involved in such undertakings at all? These issues are particularly timely, given the many billions of dollars that governments are spending worldwide to prop up troubled industries such as automobiles, as well as the urgent public efforts to encourage "green shoots" in areas such as clean-tech in the hope of stimulating economic recovery.

Programs to boost new ventures might seem like an esoteric corner of public policy, far less important than the big issues of war and peace and health benefits, not to mention the rescue of giant firms that are on the ropes, but this perception can be misleading because of the magnitude of changes that can occur when venture programs are done well.

\section{The contrasting cases}

To understand their importance, we can contrast Jamaica and Singapore. ${ }^{1}$ Both are relatively tiny

\footnotetext{
${ }^{1}$ For overviews of economic policies in Jamaica and Singapore, see Jefferson (1999) and Koh (2002). This example has benefited greatly from conversations with Peter Henry, as well as from his white paper (Henry 2006).
} 
states, with under 5,000,000 residents apiece. Upon Singapore's independence in 1965-3 years after Jamaica's own establishment as a nation-the two nations were about equal in wealth: the gross domestic product (in 2006 US dollars) was $\$ 2,850$ per person in Jamaica, slightly higher than Singapore's $\$ 2,650$. Both nations had a centrally located port, a tradition of British colonial rule, and governments with a strong capitalist orientation. (Jamaica, in addition, had plentiful natural resources and a robust tourist industry.) However, four decades later, their standing was dramatically different: Singapore had climbed to a per capita GDP of \$31,400 (2006 data, in current dollars), while Jamaica's figure was only $\$ 4,800 .^{2}$

What accounts for this amazing difference in growth rates? There are many explanations: soon after independence, Singapore aggressively invested in infrastructure such as its port, subsidized its system of education, maintained an open and corruption-free economy, and established sovereign wealth funds that made a wide variety of investments. It has also benefited from a strategic position on the key sea lanes heading to and from East Asia. Jamaica, meanwhile, spent many years mired in political instability, particularly the disastrous administration of Michael Manley during the 1970s. Dramatic shifts from a market economy to a socialist orientation and back again, with the attendant inflation, economic instability, crippling public debt, and violence, made development and implementation of a consistent long-run economic policy difficult.

Thus, in explaining Singapore's economic growth, it is hard not to give considerable credit to its policies toward entrepreneurship. The government has experimented with a wide variety of efforts to develop an entrepreneurial sector:

- The provision of public funds for venture investors seeking to locate in the city-state

- Subsidies for firms in targeted technologies

- Encouragement of potential entrepreneurs and mentoring for fledgling ventures

- Subsidies for leading biotechnology researchers to move their laboratories to Singapore

\footnotetext{
$\overline{2}$ These figures are computed using the Central Intelligence Agency (2008), Council of Economic Advisors, Executive Office of the President (2008), and the World Bank's World Development Indicators database.
}

- Awards for failed entrepreneurs (with a hope of encouraging risk-taking)

While much of the initial growth in Singapore can be attributed to sound macroeconomic policies, political stability, and various other factors, the nation's entrepreneurship initiatives have played an increasingly important role in stimulating growth.

The contrast with Jamaica is striking. Jamaica has long had a high rate of subsistence entrepreneurship; for instance, the 2006 Global Entrepreneurship Monitor survey placed it among the highest of the 42 nations it examined in various rates of entrepreneurial activity (Skeete et al. 2007). However, other data collected by the Monitor-and corroborated in anecdotal accounts-suggests that early-stage entrepreneurship is translated into full-fledged business activity at a very low rate. On this measure, the island nation ranked among the lowest nations (28th among the 35 countries ranked by GEM in 2005 (Glasgow et al. 2006)).

Some of the reasons for the inability of Jamaican entrepreneurs to grow can be seen in the World Bank's reports on the barriers to entrepreneurs. The "Doing Business" series assesses, across 178 countries, the obstacles faced by entrepreneurs in performing various standardized tasks (thereby avoiding some of the subjectivity associated with other attempts to rank entrepreneurship).

In several critical indicators, Jamaica ranked extremely low in the World Bank's 2008 analysis (International Finance Corporation 2010a). These suggest some of the barriers that hold back the growth of entrepreneurial enterprises:

- Of the 178 countries studied, Jamaica ranked 170th in the burden of complying with tax regulations. The ranking reflects not just the cost of taxes themselves, but also the administrative burdens associated with complying with the tax code. The World Bank's analysis suggests that the total cost of complying with all tax laws in Jamaica amounts to just over one-half of gross profits for the typical entrepreneur. Numerous studies have suggested that one of the most important sources of financing for the typical entrepreneur is cash flow generated by the business itself, which is plowed back into the business. If so much of entrepreneurs' income is going to meet tax obligations, business owners are 
unlikely to have the resources to invest in their enterprises. By way of contrast, Singapore ranked second worldwide, with a burden of just $23 \%$ (International Finance Corporation 2010b).

- Similarly, when the cost of registering property is compared, Jamaica ranked 108th out of 178: the cost of registering property was equal to $13.5 \%$ of the value of the property. (By comparison, the ratio in the USA is $0.5 \%$ of the value, International Finance Corporation 2010c.) The high cost of registering property means that fewer people register their holdings, which in turn leads to less secure property rights. Most critically, entrepreneurs who do not hold a firm legal title to property are unlikely to be able to borrow against this holding from a bank. Once again, this comparison suggests that entrepreneurs have fewer resources for growing their enterprises.

One of the most visible manifestations of this lack of activity may be in Jamaica's productivity: from 1973 to 2007, the nation actually experienced negative productivity growth (Henry 2006).

Making this poor performance even more striking is the fact that, during this period, the developed nations experienced substantial growth through the implementation of information technology, and many developing markets experienced even faster growth as they caught up with technologies adopted earlier in the West.

This disparity may change in future years: Jamaica enjoyed a surge in income with the rise of energy and commodity prices, and the most recent prime ministers have shown greater awareness of, and willingness to lower, barriers to entrepreneurship. However, the disparate experiences of Singapore and Jamaica over the past four decades demonstrate why all of us should care about public efforts to stimulate entrepreneurship.

Thus, while the dollars spent each year on entrepreneurship programs-though significant on an absolute basis - pale when compared with defense and health care expenditures, the picture changes when we consider the long-run consequences of policies that facilitate or hinder the development of a venture sector, i.e., the impact on national prosperity of a vital entrepreneurial climate. In the long run, the significance of entrepreneurial policies looms much larger.

\section{A more systematic view}

When we look at the academic literature, we find arguments for and against government interventions to stimulate entrepreneurship. The rationales for government investment rest on three pillars.

First, the role of technological innovation as a spur for economic growth is now widely recognized. Economists have documented the strong connection between technological progress and economic prosperity, both across nations and over time. This insight grew out of studies done by the pioneering student of technological change, Morris Abramowitz (1956). He realized that there are ultimately only two ways of increasing the output of the economy: (1) increasing the number of inputs that go into the productive process (e.g., by having workers stay employed until the age of 67, instead of retiring at 62), or (2) developing new ways to get more output from the same inputs. Abramowitz measured the growth in the output of the US economy between 1870 and 1950the amount of material goods and services producedand then computed the increase in inputs (especially labor and financial capital) over the same time period. To be sure, this was an imprecise exercise: he needed to make assumptions about the growth in the economic impact of these input measures. After undertaking this analysis, he discovered that growth of inputs between 1870 and 1950 could account for only about $15 \%$ of the actual growth in the output of the economy. The remaining $85 \%$ could not be explained through the growth of inputs. Instead, the increased economic activity stemmed from innovations in getting more stuff from the same inputs.

Other economists in the late 1950s and 1960s undertook similar exercises. These studies differed in methodologies, economic sectors, and time periods, but the results were similar. Most notably, Robert Solow, who later won a Nobel Prize for this work, identified an almost identical "residual" of about $85 \%$ (Solow 1957). The results were so striking because most economists for the previous 200 years had been building models in which economic growth was treated as if it were primarily a matter of adding more inputs: if you just had more people and dollars, more output would invariably result.

Instead, these studies suggested, the crucial driver of growth was changes in the ways inputs were used. 
The magnitude of this unexplained growth, and the fact that it was exposed by researchers using widely divergent methodologies, persuaded most economists that innovation was a major force in the growth of output.

In the decades since the 1950s, economists and policymakers have documented the relationship between innovation-whether new scientific discoveries or incremental changes in the way that factories and service businesses work-and increases in economic prosperity. Not just identifying an unexplained "residual," studies have documented the positive effects of technological progress in areas such as information technology. Thus, an essential question for the economic future of a country is not only what it produces, but how it goes about producing it.

This relationship between innovation and growth has been recognized by many governments. From the European Union-which has targeted increasing research spending as a key goal in the next few years - to emerging economies such as China, leaders have embraced the notion that innovation is critical to growth.

Second, academic research has highlighted the role of entrepreneurship and venture capital in stimulating innovation. Hundreds, if not thousands, of papers have examined the relationship between firm size and innovation. ${ }^{3}$ Much of this work has related measures of innovative discoveries - for example, research and development (R\&D) expenditures, patents, or inventions-to firm size. Initial studies were undertaken using the largest manufacturing firms; more recent works have employed larger samples and detailed data (e.g., studies employing data on firms' specific lines of business). Despite the improved methodology of recent studies, the results have remained inconclusive: the studies seem as likely to find a negative as a positive relationship, and even when a positive relationship between firm size and innovation has been found, it has had little economic significance. For instance, one study concluded that a doubling of firm size increased the ratio of $R \& D$ to sales by only $0.2 \%$ (Cohen et al. 1987).

Whatever the relationship between a firm's size and its innovations, one of the relatively few things that researchers can agree on is the critical role

\footnotetext{
3 The interested reader can turn to surveys by Azoulay and Lerner (2010) and Cohen and Levin (1989).
}

played by new firms, or entrants, in many industries. The role of start-ups in emerging industries has been highlighted not just in many case studies but also in systematic research. For instance, a study by Acs and Audretsch (1988) examined which firms developed some of the most important innovations of the 20th century. They documented the central contribution of new and small firms: these firms contributed almost half the innovations they examined. However, they found that the contribution of small firms was not central in all industries. Rather, their role was a function of industry conditions: it was greatest in immature industries in which market power was relatively unconcentrated. These findings suggest that entrepreneurs and small firms play a key role in observing where new technologies can meet customers' needs, and rapidly introducing products.

Venture financiers and firms have developed tools that are very well suited to the challenging task of nurturing high-risk but promising new ideas. One study estimates that, because of these tools, a single dollar of venture capital generates as much innovation as three dollars of traditional corporate research and development. Venture capital and the entrepreneurs it funds will never supplant other wellsprings of innovation, such as vibrant universities and corporate research laboratories (in an ideal world, these components of growth all feed each other). However, in an innovative system, a healthy entrepreneurial sector and venture capital industry will be important contributors.

If this were the whole story, the case for public involvement would be pretty compelling. However, the case for public intervention rests as well on a third leg: the argument that governments can effectively promote entrepreneurship and venture capital, and this is a much shakier assumption.

To be sure, entrepreneurial markets have features that allow us to identify a natural role for government in encouraging their evolution. Entrepreneurship is a business in which there are increasing returns. To put the point another way, it is far easier to found a startup if there are ten other entrepreneurs nearby. In many respects, founders and venture capitalists benefit from their peers; for instance, if entrepreneurs are already active in the market, investors, employees, intermediaries such as lawyers and data providers, and the wider capital markets are likely to be knowledgeable about the venturing process and what 
strategies, financing, support, and exit mechanisms it requires. In the activities associated with entrepreneurship and venture capital, the actions of any one group are likely to have positive spillovers-or, in the language of economics, "externalities"-for their peers. It is in these types of settings that government can often play a very positive role as a catalyst.

This observation is supported by numerous examples of government intervention that has triggered the growth of a venture capital sector. For instance, the Small Business Investment Company (SBIC) program in the USA led to the formation of the infrastructure for much of the modern venture capital industry. Many of the early venture capital funds and leading intermediaries in the industry - such as law firms and data providers-began as organizations oriented to the SBIC funds, and then gradually shifted their focus to independent venture capitalists. Similarly, public programs played an important role in triggering the explosive growth of virtually every other major venture market around the globe.

However, there are reasons to be cautious about the efficacy of government intervention. In particular, two well-documented problems can derail government programs. First, they can simply get it wrong, allocating funds and support in an inept or, even worse, counterproductive manner. An extensive literature has examined the factors that affect the quality of governmental efforts in general, and suggests that more competent programs are likelier in nations that are wealthier, with more heterogeneous populations, and an English legal tradition.

Economists have also focused on a second problem, delineated in the theory of regulatory capture. These writings suggest that private- and public-sector entities will organize to capture direct and indirect subsidies that the public sector hands out; for instance, programs geared toward boosting nascent entrepreneurs may instead end up boosting cronies of the nation's rulers or legislators. The annals of government venturing programs abound with examples of efforts that have been hijacked in such a manner.

A few instances of both problems are as follows:

- In its haste to roll out the Small Business Investment Company program in the early 1960s, the US Small Business Administration chartered-and funded-hundreds of funds whose managers were incompetent or crooked.
- The incubators taking part in Australia's 1999 Building on Information Technology Strengths (BITS) program frequently captured the lion's share of the subsidies aimed toward entrepreneurs, by forcing the young firms to purchase their own overpriced services.

- Malaysia opened a massive BioValley complex in 2005 with little forethought about whether there would be demand for the facility. The facility soon became known as the "Valley of the BioGhosts."

- UK Labour and Conservative governments subsidized and gave exclusive rights in the 1980s to the biotechnology firm Celltech, whose management team was manifestly incapable of exploiting those resources.

- Norway squandered much of its oil wealth in the 1970s and 1980s propping up failing ventures and funding ill-conceived new businesses begun by relatives of parliamentarians and bureaucrats.

\section{The right steps}

What public policies are most effective in encouraging the growth of a venture economy? Before turning to general principles, these can be illustrated by considering two success stories.

In June 1992, the Israeli government established Yozma Venture Capital Ltd., a US \$100 million fund wholly owned by the public sector. At the time, there was a single venture fund active in the nation, Athena Venture Partners. While there were certainly welltrained engineers in the nation working on promising technologies, entrepreneurs (and would-be company founders) were suspicious of venture investors. This reluctance was based in part on their interactions with the pioneering venture capitalists in the nation, as well as their general skepticism about selling equity to unaffiliated parties. Instead, they preferred to rely on bank debt for financing. The only problem, of course, was that such financing was rarely available for young, risky ventures.

The key goal of Yozma was to bring foreign venture capitalists' investment expertise and network of contacts to Israel. The need for this assistance was highlighted by the failure of the nation's earlier efforts to promote high-technology entrepreneurship. 
One assessment concluded that fully $60 \%$ of the entrepreneurs in prior programs had been successful in meeting their technical goals but nonetheless failed because the entrepreneurs were unable to market their products or raise capital for further development (Jerusalem Institute of Management 1987). Foreign expertise was seen as key to overcoming this problem.

Accordingly, Yozma actively discouraged Israeli financiers from participating in its programs. Rather, the focus was on getting foreign venture investors to commit capital for Israeli entrepreneurs. The government provided matching funds to investors, typically US $\$ 8$ million of a US $\$ 20$ million fund. The venture fund was given the right to buy back the government stake within the first 5 years for the initial value plus a preset interest rate of roughly 5-7\%. Thus the incentives of Yozma meant that the government provided an added incentive to the venture fund if the investments proved successful. Moreover, learning from the nation's misadventures during earlier programs to stimulate the venture industry-when cumbersome application procedures and burdensome reporting requirements discouraged participationthe administration of the program was deliberately made simple.

In addition to the financial incentives, the project adopted a legal structure for the venture funds that foreign investors would be comfortable with. Included were features such as a 10-year fund life, limited partnerships modeled after the Delaware partnerships that are standard practice in the USA and elsewhere, and "flow-through" tax status. Had the government not adopted these features-and the Israeli Treasury department resisted them before acquiescing under pressure-it is unlikely that the program would have succeeded in attracting foreign investors.

The Yozma program delivered beyond the wildest dreams of the founders. Ten groups took advantage of this offer, mostly from the USA, Western Europe, and Japan. Many of the original Yozma funds, including Gemini and Walden Ventures, earned spectacular returns and served as precursors to larger, follow-on funds. Moreover, many of the local partners recruited by the overseas venture capitalists were able to spin off and establish their own firms, which global venture capitalists were eager to fund because of their impressive track records. (A Yozma "alumni club" allows groups to learn from each others' experiences while making these transitions.) One decade after the program's inception, the ten original Yozma groups were managing Israeli funds totaling US \$2.9 billion, and the Israeli venture market had expanded to include 60 groups managing approximately US $\$ 10$ billion (Erlich 2003). In most tabulations, Tel Aviv has surpassed Boston as the urban area with the most venture activity after San Francisco.

Another, albeit younger and less conclusive, success is the New Zealand Venture Investment Fund (NZVIF). ${ }^{4}$ In late 1999 the newly elected Prime Minister, Helen Clark, realized that New Zealand faced a fundamental problem and needed to change. In particular, she was concerned that New Zealand's economy depended critically on production and exporting of commodities. The nation's position in the knowledge-based industries was weak, and its living standards were steadily falling relative to the other major developed nations.

A critical area that her government targeted was enhancing innovation, and encouraging venture capital was a critical aspect of this goal. In light of limited activity in the local market, the government sought to accelerate the growth of the New Zealand venture capital market through co-investment with private investors and related market development activities. After a careful review of other models, the government adopted a so-called fund-of-funds approach, whereby it made investments in private venture capital fund managers.

Prior to any investments being made, NZVIF was structured as a stand-alone company, which ensured that the government could distance itself from risk and liability for the investments made. This approach also ensured distance and independence from decisions about appointment of venture capital fund managers and from individual investment decisions.

These investments were structured as equity (to minimize possible distortions) and could be bought out by the investors. Government investments in the funds were on the same terms as those of private investors, except that each fund was provided with an option exercisable up to the end of the fifth year of the fund to buy out the NZVIF investment on

\footnotetext{
${ }^{4}$ For a detailed history and analysis of the program, see Lerner et al. (2005).
} 
the basis of capital plus interest only (that is, other investors would receive any upside above this amount).

Deliberately, the project's designers asked for no special rights. The fund managers were given responsibility for making and managing investments without government interference. NZVIF leaders participated in investor governance decisions on the same terms as private investors, with the same voting rights. Investor governance arrangements reflected current market practice. The funds were geared toward investors in early-stage companies, and every dollar had to be matched with two dollars from the private sector.

NZVIF's decision to invest in a fund is made following completion of an extensive selection and due diligence process, undertaken by the fund manager, to determine whether the fund proposal is "investment grade." An important process is the establishment of the fund through a process of competitive selection. The initial screening is done by the staff, followed by an outside assessment by an independent specialist private equity advisor. A standard methodology and fixed criteria are used to assess and rank all applications. In many cases, the staff work actively with teams of would-be venture fund managers to help them make their proposals more attractive (for instance, helping them identify prospective additional individuals who can contribute needed experience). This is necessitated by the limited supply of New Zealand-based funds. Following the completion of external due diligence, the NZVIF board selects those applicants with whom it wishes to negotiate investment terms.

As part of the negotiations, a monitoring and reporting framework is agreed with each NZVIF seed fund manager. This enables NZVIF to collect the economic and financial data it needs for the required regular reports on the performance of each fund and the impact of the program. This also enables NZVIF to monitor each fund to ensure it is compliant with its investment agreement and investor governance requirements. Once fund agreements are finalized, investment activity commences. While the program is still young, its success to date has been very promising.

More generally, three principles in particular seem critical as guide-posts:

Remember that entrepreneurial activity does not exist in a vacuum. Entrepreneurs are tremendously dependent on their partners. Without experienced lawyers able to negotiate agreements, skilled marketing gurus and engineers who are willing to work for low wages and a handful of stock options, and customers who are willing to take a chance on a young firm, success is unlikely. However, despite the importance of the entrepreneurial environment, in many cases government officials hand out money without thinking about barriers other than money that entrepreneurs face. In some cases, crucial aspects of the entrepreneurial environment may seem tangential, for instance, the importance of robust public markets for young firms as a spur to venture investment. It is critical to take a broad view and address not just the availability of capital but also other components of a productive arena in which entrepreneurs could operate.

Let the market provide direction. The two successful efforts we have highlighted above, the Israeli Yozma program and the New Zealand Venture Investment Fund, differed in their details: the former was geared toward attracting foreign venture investors; the latter encouraged locally based, early-stage funds. However, they shared a central element: each used matching funds to determine where public subsidies should go. In using the market for guidance, policymakers should keep in mind that these initiatives should not compete with independent venture funds or finance substandard firms that cannot raise private capital. Emulating successful initiatives in the past, programs should require that a substantial amount of funds be raised from nonpublic sources. To be sure, in encouraging seed companies and groups, leaders should be aware that extensive intervention may be needed before they are "fund-able." Programs may need to work closely with the organizations to refine strategies, recruit additional partners (perhaps even from other regions), and identify potential investors. However, only through a market-based system are the critical flaws that have doomed so many earlier programs likely to be avoided.

Resist the temptation to overengineer. In many instances, government requirements that limit the flexibility of entrepreneurs and venture investors have been detrimental. It is tempting to add restrictions on several dimensions, for instance: the locations in which the firms can operate, the type of securities venture investors can use, and the evolution of the firms (e.g., restrictions on acquisitions or secondary 
sales of stock). Government programs should eschew such efforts to micromanage the entrepreneurial process. While it is natural to expect that firms and groups receiving subsidies will retain a local presence or continue to target the local region for investments, these requirements should be as minimal as possible.

We can also highlight a few other points that are important to success:

- Leverage the local academic scientific and research base. One particular precondition to entrepreneurship deserves special mention: in many regions of the world, there is a mismatch between the low level of entrepreneurial activity and venture capital financing, on the one hand, and the strength of the scientific and research base, on the other. The role of technology transfer offices is absolutely critical here. Effective offices do not just license technologies but also educate nascent academic entrepreneurs and introduce them to venture investors. Building the capabilities of local technology transfer offices, and training both potential academic entrepreneurs and technology transfer personnel in the process of new firm formation, is essential. All too often, technology transfer offices are encouraged to maximize the short-run return from licensing transactions. This leads to an emphasis on transactions with established corporations that can make substantial up-front payments, even though licensing new technologies to start-ups can yield substantial returns in the long run, both to the institution and to the region as a whole. It is important that policymakers think seriously about the way in which technology transfer is being undertaken, the incentives being offered, and their consequences.

- Respect the need for conformity to global standards. It is natural to want to hold onto longstanding approaches in matters such as securities regulation and taxes. In many cases, these approaches have evolved to address specific problems, and have proven to be effective. Nevertheless, there is a strong case for adopting the de facto global standards. Global institutional investors and venture funds are likely to be discouraged if customary partnership and preferred stock structures cannot be employed in a given nation. Even if a perfectly good alternative exists, they may be unwilling to devote the time and resources to explore it. Unless the nation is one such as China-where global investors feel compelled to master the system, no matter how complex, owing to the size of the market opportunity-policymakers should allow transactions that conform to the models widely accepted as best practice.

- Recognize the long lead times associated with public venture initiatives. One of the common failings of public entrepreneurship and venture capital initiatives has been impatience. Building an entrepreneurial sector is a long-run endeavor, not an overnight accomplishment. Programs that have initial promise should be given time to prove their merits. Far too often, promising initiatives have been abandoned on the basis of partial (and often, not the most critical) indicators, for instance, low interim rates of return of initial participants. Impatience - or creating rules that force program participants to focus on short-run returns-is a recipe for failure.

- Avoid initiatives that are too large or too small. Policymakers must walk a tightrope in finding the appropriate size for venture initiatives. Too small a program will do little to improve the environment for pioneering entrepreneurs and venture funds. Moreover, inflated expectations, out of proportion to the money invested, may create a backlash that impedes future efforts. However, programs that are too substantial can swamp local markets. The imbalance between plentiful capital and limited opportunities may introduce pathologies. Unsuccessful programs, such as the Canadian Labor Fund Program, not only backed incompetent groups that did little to spur entrepreneurship, but it crowded out some of the most knowledgeable local investors.

- Understand the importance of global interconnections. Entrepreneurship and venture capital are emerging as global enterprises. This evolution has two important consequences. First, no matter how eager policymakers are to encourage activity in their own backyard, they must realize that, to be successful, firms must have a multinational presence. Efforts to restrict firms to hiring and manufacturing locally are likely to be selfdefeating. Second, it is important to involve overseas investors as much as feasible. Local 
companies can benefit from relationships with funds based elsewhere but investing capital locally. Moreover, successful investments will attract more overseas capital. In addition, local affiliates of a fund based elsewhere-having a successful track record-will gain the credibility they need to raise their own funds. That being said, when public funds subsidize activities by overseas parties, officials should obtain commitments from these entrepreneurs and groups to recruit personnel to be resident locally, and to have partners based elsewhere be involved with the management of the local groups.

- Institutionalize careful evaluations of initiatives. All too often, in the rush to boost entrepreneurship, policymakers make no provision for the evaluation of programs. The future of initiatives should be determined by their success or failure in meeting their goals, rather than other considerations (such as the vehemence with which supporters argue for their continuation). Careful program evaluations will help ensure better decisions. These evaluations should consider not just the individual funds and companies participating in the programs, but also the broader context.

- Realize that programs need creativity and flexibility. Too often, public venturing initiatives are like the pock-faced villain in a horror film-as much as one tries, he cannot be killed off. Their seeming immortality reflects the capture problem discussed above: powerful vested interests coalesce behind initiatives, making them impossible to get rid of. The nations that have been most successful in public programs have been willing to end those that are not doing well, and to substitute other incentives. Even more powerfully, they have been willing to end programs on the grounds that they are too successful and hence no longer in need of public funding. Moreover, program rules may have to evolve, even if important classes of participants are thereby eliminated. If government is going to be in the business of promoting entrepreneurship, it needs some entrepreneurial qualities itself.

- Recognize that "agency problems" are universal and take steps to minimize their danger. The "horror stories" above illustrate that the temptations to direct public subsidies in ways not intended are not confined to any region, political system or ethnicity. While we might wish that human beings everywhere would confine themselves to maximizing public welfare, selfish interest all too often rears its ugly head. In designing public programs to promote venture capital and entrepreneurship, such behavior should be limited as far as possible. Defining and adhering to clear strategies and procedures for venture initiatives, creating a firewall between elected officials and program administrators, and careful assessments of the program can help limit self-serving behavior.

- Make education an important part of the mixture. The emphasis on education should have at least three dimensions:

- The first is building the understanding of outsiders about the local market's potential. One of the critical barriers to the willingness of venture investors to invest in a given nation is lack of information. If one visits a racetrack for the first time, it is always nice to know whether the track favors front-runners or late closers, and who the hot local jockeys are. In the same way, institutions feel more comfortable investing if they have information about the level of entrepreneurial activity in local markets, the outcomes of the investments, and so forth. An important role that government can play is gathering this information, or else encouraging (and perhaps funding) a local trade association to do so.

- Second, educating entrepreneurs is a critical process. In many emerging venture markets, entrepreneurs may have a great deal of confidence, but relatively little understanding of the expectations of top-tier private investors, potential strategic partners, and investment bankers. The more that can be done to fill these gaps, the better.

- Finally, a broad-based understanding in the public sector of the challenges of entrepreneurial and venture capital development is very helpful. As we have repeatedly highlighted, policymakers have made expensive errors out of a lack of understanding of how these markets really work. 


\section{Concluding remarks}

This essay explores the appropriate role for public policy in the promotion of venture capital and highpotential entrepreneurship. The case for supporting these institutions lies in the importance of innovation in stimulating economic growth, the role of entrepreneurial firms as an engine of innovation, and the historical evidence and theoretical arguments that suggest that governments can play a role in promoting entrepreneurship. At the same time, many barriers exist to effective implementation of public programs with these goals. The article explores the frequently encountered challenges and the principles that can lead to more effective programs.

The promotion of new business ventures is of critical importance to all of us. While the challenges facing government initiatives may seem arcane and technical, well-considered policies are likely to profoundly influence our opportunities, as well as those of our children and grandchildren. Misguided policies, unfortunately, will also help determine the future. However challenging the encouragement of entrepreneurship may seem, it is truly too important to be left to policy specialists.

Acknowledgments Josh Lerner thanks Harvard Business School's Division of Research for financial support.

Open Access This article is distributed under the terms of the Creative Commons Attribution Noncommercial License which permits any noncommercial use, distribution, and reproduction in any medium, provided the original author(s) and source are credited.

\section{References}

Abramowitz, M. (1956). Resource and output trends in the United States since 1870. American Economic Review, 46(2), 5-23.

Acs, Z. J., \& Audretsch, D. B. (1988). Innovation in large and small firms: An empirical analysis. American Economic Review, 78(4), 678-690.

Azoulay, P., \& Lerner, J. (2010). Technological innovation and organizations. In R. Gibbons \& J. Roberts (Eds.), Handbook of organizational economics. Princeton: Princeton University Press (forthcoming).
Central Intelligence Agency. (2008). World fact book. Langley: CIA.

Cohen, W. M., \& Levin, R. C. (1989). Empirical studies of innovation and market structure. In R. Schmalensee \& R. D. Willig (Eds.), Handbook of industrial organization (Vol. 2). New York: North-Holland.

Cohen, W. M., Levin, R. C., \& Mowery, D. C. (1987). Firm size and R\&D intensity: A re-examination. Journal of Industrial Economics, 35(4), 543-563.

Council of Economic Advisors, Executive Office of the President. (2008). Economic Report of the President. Washington, DC: Government Printing Office.

Erlich, Y. (2003). The Yozma Group—-policy and success factors. Retrieved May 24, 2010 from http://www.insme.org/ documenti/Yozma_presentation.pdf.

Glasgow, S., Williams-Myers, C., Skeete, V., \& Ismail, O. A. (2006). Global Entrepreneurship Monitor: 2005 Jamaica Report. Kingston: University of Technology.

Henrekson, M., \& Lundström, A. (2009). The Global Award for Entrepreneurship Research. Small Business Economics, 32(1), 1-14.

Henry, P. (2006). The Jamaican economy: Maintaining stability and moving to growth. Working paper. Stanford University.

International Finance Corporation. (2010a). Doing business: Jamaica. Retrieved May 24, 2010 from http://www.doing business.org/ExploreEconomies/?economyid=97.

International Finance Corporation. (2010b). Doing business: Singapore. Retrieved May 24, 2010 from http://www. doingbusiness.org/ExploreEconomies/?economyid=167.

International Finance Corporation. (2010c). Doing business: United States. Retrieved May 24, 2010 from http://www. doingbusiness.org/ExploreEconomies/?economyid=197.

Jefferson, O. (1999). Stabilization and stagnation in the Jamaican economy, 1972-97: Some reflections on macroeconomic policy over the past twenty-five years. Kingston: University of the West Indies.

Jerusalem Institute of Management. (1987). Export-led growth strategy for Israel. Jerusalem: Jerusalem Institute of Management and the Telesis Group.

Koh, A. T. (Ed.) (2002). The Singapore economy in the 21st century: Issues and strategies. New York: McGraw-Hill.

Lerner, J. (2009). Boulevard of broken dreams: Why public efforts to boost entrepreneurship and venture capital have failed-and what to do about it. Princeton: Princeton University Press.

Lerner, J., Moore, D., \& Shepherd, S. (2005). A study of New Zealand's venture capital market and implications for public policy: A report to the Ministry of research science and technology. Auckland: LECG.

Skeete, V., Williams-Myers, C., Ismail, O. A., \& Glasgow, S. (2007). Global Entrepreneurship Monitor: 2006 Jamaica Report. Kingston: University of Technology.

Solow, R. M. (1957). Technical change and the aggregate production function. Review of Economics and Statistics, 39(3), 312-320. 